\title{
The right to silence: in constitutional limbo
}

\author{
by John Breslin
}

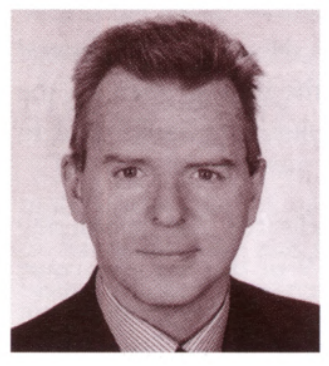

It has been held that the right of silence is implicit in the right to a fair trial expressed in the European Convention on Human Rights. John Breslin reviews Irish authority to see how the privilege against self-incrimination operates within a constitutional framework; of particular interest should the UK pass a Bill of Rights.

$\mathrm{T}$ The extent of the freedoms embodied in the right to silence is difficult to define precisely (Thomas, 'The So-Called Right to Silence' (1990-91) 14 New Zealand Universities Law Review, 299; Breslin, 'Self-Incrimination: Recent Developments' (1996) 4 Journal of Financial Crime 47). This is partly because the right is founded on judge-made law alone and has never been comprehensively codified. Even in jurisdictions where fundamental rights and freedoms have been committed to writing in the form of a Constitution or Bill of Rights, the right to silence or privilege against self-incrimination has not necessarily been expressly guaranteed. The Irish Constitution of 1937 and the European Convention on Human Rights (ECHR) are examples. Although the right is not expressly guaranteed by the ECHR, it has been held that it is implicit in the express right to a fair trial guaranteed by art. 6 of the ECHR (Saunders $v$ UK (1997) 23 ECHRR 313).

The law on the right to silence is, of course, highly emotive and has become complex, making it ever more difficult to identify the true basis for the exercise of the right and to identify when its boundaries have been transgressed in a given case. For example: is the privilege available to a company? The High Court of Australia has held, in the context of an investigation into alleged environmental pollution, that the right may only be claimed by individuals, not companies (Environmental Protection Authority v Caltex Refining Co Pty Ltd (1992-93) 178 CLR 477). The English courts have held, in a similar context, that the right has no role in preventing the regulatory authorities gaining access to relevant documentation (Re Green Environmental Industries Ltd, The Times, 9 October 1997).

In the October 1997 issue of Amicus Curiae (Issue 2, p. 21) Victor Tunkel comprehensively reviewed the impact of the Saunders decision on English criminal practice. The purpose of this article is to refer to Irish authority to see how the privilege against self-incrimination operates within a constitutional framework. This may be of interest if a Bill of Rights is passed in the UK. Secondly, it will be submitted that the Saunders decision is fundamentally flawed and should not be followed, either at the level of the European Court of Human Rights, or at domestic level, should the UK and Ireland incorporate the ECHR into their respective domestic laws.

\section{RECENT IRISH CASE LAW}

The Irish Supreme Court handed down a fundamentally important decision on the constitutional basis of the right to silence in Heaney $v$ Ireland [1997] 1 ILRM 117. The defendants in that case were convicted under a section in the Offences Against the State Act 1939 which required a suspect held in custody to give to a police officer an account of his movements. Failure to give such an account, or giving a false or misleading account, is a criminal offence under the section. The defendants challenged the constitutionality of the section under a number of headings, including that the provision infringed the defendants' right to silence.

The Supreme Court analysed the exercise of the right to silence in the context of the right to freedom of expression guaranteed by art. 40 of the Constitution. O'Flaherty J (giving the judgment of the court) held that the right to silence is 'but a corollary of' the right of freedom of expression. A series of decisions made it clear that it is permissible for the legislature to abrogate and qualify the exercise of the right of freedom of expression, to protect other legitimate interests of the state. In particular, O'Flaherty held that:

' the State is entitled to encroach on the right of the citizen to remain silent in pursuit of its entitlement to maintain public peace and order.' (at p. 127)

The state must encroach on the rights of the citizen as little as possible, but:

'the innocent person has nothing to fear from giving an account of his or her movements, even though on grounds of principle, or in the assertion of constitutional rights, such a person may wish to take a stand. However, the court holds that the prima facie entitlement of citizens to take such a stand must yield to the right of the State to protect itself. A fortiori, the entitlement of those with something relevant to disclose concerning the commission of a crime to remain mute must be regarded as of a lesser order.' (at p. 127-8)

The implications of this approach were illustrated in two subsequent cases concerning Ireland's recent legislation designed to combat drug-trafficking and organised crime, the Proceeds of Crime Act 1996. 


\section{M v D}

The first is $M V D$ (unreported), High Court, 10 December 1996, Moriarty J. Under the 1996 Act, the police are given the power to apply to the court for an order freezing the assets of any person suspected of the commission of serious crime, including drug-trafficking. Furthermore, the police can apply for an order directing the suspect to specify, on affidavit, details of all property in his possession or control, together with his income and sources of income, during the ten years prior to the application. Moriarty J was sceptical of arguments such as 'the innocent have nothing to fear'. Furthermore, he declined to follow Leggatt J's view (Re Thomas (Disclosure Order) [1992] 4 All ER 814), that disclosure of assets did not amount to selfincrimination, but merely facilitated an assessment of the amount to be recovered from a defendant who benefited from drug-trafficking. Nonetheless, on the basis of the Heaney decision, Moriarty J took the view that the 1996 Act represented a justifiable and proportionate interference with the respondent's right to silence (although he reduced the period in respect of which the respondent was to account for his property and income from ten to six years). In this regard his Lordship further held that any retrospective effect of the Act was fully justified.

His Lordship indicated that he expected that the furnishing of information under the Act should be subject to an undertaking by the prosecution not to use the information in any subsequent criminal trial. Mr Tunkel points out that this appears to be the state of affairs in which investigators find themselves as a result of the Saunders decision (see below). The Supreme Court has not yet commented on this judicial restriction on the powers of the prosecutors; it would, on any practical analysis, appear to emasculate the effectiveness of the powers under the 1996 Act. It is submitted that to permit compulsory questioning so as to provide 'leads', but not evidence which can be used at trial, makes no sense in principle. By forcing the defendant to provide the information one is thereby exposing him to the prospect of self-incrimination. If the information turns out to be false, the defendant can be prosecuted (see the judgment of Walsh J in Saunders: the privilege, if it is to be afforded, must logically extend to all information which furnishes a link in the chain of evidence needed to secure a conviction).

Furthermore restricting the use to which the information can be put is open to criticism on practical, as well as theoretical, grounds. It merely promotes a 'cat and mouse' game where the prosecutor, having been given clues (which may or may not be accurate), must follow them up on the off-chance that the clues will not lead up a blind alley, and will lead him to stumble upon evidence which is otherwise admissible. It also exacerbates the risk that the defendant will supply false information, in the knowledge that it cannot be tested under cross-examination or used to undermine the defendant's credibility.

\section{GILLIGAN}

The effect of the Heaney judgment was further considered in Gilligan v The Criminal Assets Bureau (unreported), High Court, 26 June 1997, McGuinness J. The plaintiff's assets were frozen pursuant to the Proceeds of Crime Act 1996: he challenged the constitutionality of the Act on a number of grounds including that the obligation to state his sources of income failed to protect his privilege against self-incrimination and failed to uphold the presumption of innocence in criminal cases. He also argued that the provision breached art. 6 of the ECHR which guaranteed his right to a fair trial.
McGuinness J pointed out that the ECHR does not form part of the domestic law of the state (Re O'Laighleis [1960] IR 93; Norris v Attorney General [1984] IR 36). Furthermore because the remedies under the 1996 Act were civil, not criminal in nature, she rejected the contention that the effect of the Act was to reverse the burden of proof. The legislature in the context of civil forfeiture proceedings was entitled to apportion the burden as it saw fit, free from any constitutional strictures. In any event, the disclosure of assets and their source did not detract from the state's obligation, in any ensuing criminal prosecution, to prove its case beyond reasonable doubt. Like Moriarty J, however, McGuinness J was sceptical of 'the innocent have nothing to fear' argument as to the right to silence. However being bound by the Heaney decision, she held that the infringement on the plaintiff's right to silence was not absolute and could yield to other policy considerations.

Her Lordship followed $M_{v} D$ and indicated that in ordering the plaintiff to give evidence under s. 9 of the Act, the court might require an undertaking from prosecuting authorities not to profit directly from the information in any subsequent prosecution. She recognised that it might not be possible to enforce such an undertaking completely.

\section{THE DECISION IN SAUNDERS}

As is well known, the European Court of Human Rights ("the court') held that the conviction of Mr Ernest Saunders in the context of the Guinness takeover was unfair because statements made by him, under compulsion, to Companies Act inspectors were used in his subsequent trial ((1997) 23 ECHRR 313). This was so even though the trial judge excluded statements so made by him after being charged, and even though the defendant chose to go into the witness box, thereby putting himself in the position of being confronted with the statements in cross - examination.

The majority judgment is not altogether free from difficulty. The court made some extremely far-reaching statements. It concluded that even if the statement made under compulsion did not actually incriminate the defendant, it would still be excluded under the privilege if it were used during the trial, e.g. to attempt to undermine his credibility (at p. 338-9). Thus the court adopted an extremely broad definition of what an incriminating statement is. The court refused to undertake any evaluation of the public interest in the prevention of crime of a particular kind. So the court ducked the legitimate and, it is submitted, necessary process of evaluating the status of the right in comparison with other social interests. This was so even in the light of the court's earlier decision in Murray (1996) 22 ECHRR 29 , to the effect that the right is not an absolute one. Furthermore, the court indicated that it would only take into account local law safeguards if they operated to exclude the evidence. The effect of this remarkable stance is, of course, that in-built protections, such as those available under statute or the trial judge's inherent jurisdiction, will never be taken into account.

There are, furthermore, some intellectual weaknesses in the majority reasoning in Saunders. The majority hinted that the concerns which led it to rule the references to the pre-trial interrogation unfair, would not apply to situations where the evidence obtained had an existence 'independent' of the will of the defendant (at p. 337-8). The court cited examples of documents seized from the defendant, DNA samples taken from 
bodily tissue, and urine samples. But if such items are taken from the defendant under compulsion, what difference in principle can it make that these items are of a physical nature and do not comprise statements which the defendant has made? The court provided no clue and, indeed, one is hard to divine. It is surely the existence of the element of compulsion which founds the privilege, not the nature of the evidence.

Perhaps the most surprising aspect of the court's reasoning was its emphasis, on the one hand, of the role of the statements in securing the defendant's conviction (at p. 320-1 and 339), whilst stating later in the judgment that the court could not be sure that there would have been no conviction had the statements not been used (at p. 342).

\section{CONCLUSIONS}

The Saunders decision is troubling, not only for those involved in the prosecution of serious financial crime, but also for advisers of defendants who may have a legitimate claim that the right has been breached in circumstances where a remedy should be afforded. The decision foments uncertainty and displays the fundamental divisions among judges from various jurisdictions on the nature, extent and applicability of the right. The right hovers in a constitutional limbo, with no foundation and few definite criteria as to when it can successfully be invoked. Complications arise in identifying the status of the privilege when one considers the argument, summarised by Lord Bingham, that the convention is part of EU law in so far as specifically recognised by the Court of Justice (Lord Bingham The European Convention on Human Rights: Time to Incorporate (1993) 109 LQR 390, at p. 400). As such, national courts are required to recognise and give effect to the convention in the area of community law. The impact of this principle of incorporation through the 'back door', in the area of domestic enforcement of the criminal law, is perhaps unclear at present.

\section{Individual states should decide}

Requiring cases on the right to silence under the convention to be handled (at first instance) on a supranational level is to expect extraordinary feats of the judges of the court. The right to silence is so intimately connected with the signatory state's enforcement of criminal policies that it must be left to those states alone (and their own appellate courts) to decide primarily on the rights of citizens in this context. It is too much to expect a judge from one jurisdiction to be so familiar with other signatory states' policy concerns as to give a coherent evaluation of an alleged violation (see Lord Bingham). To date the court has not attached sufficient weight to the interests of subsidiarity, i.e. the ability of a signatory state to deal with a local problem in the manner it sees fit - the decentralisation of power in the European Union. The same might be said about other contentious rights, - the right to privacy. Until the convention is incorporated into domestic law (both British and Irish) it is perhaps unreasonable to expect that conditions will exist whereby the court will begin to trust local legislatures and courts in a more meaningful way.

The right will find its way into English domestic law in some form in the context of the proposed Bill of Rights. (This course of action is not yet proposed in Ireland, to the best of the author's knowledge. Certain fundamental human rights are already guaranteed by the Irish Constitution: the task of marrying the Irish Constitution with the European Convention will be formidable, if it were ever attempted.) A very real tension will emerge between traditional English jurisprudence on the topic, which tends to be more permissive of interference with the right (see, for example, Bishopsgate Investment Management Ltd $\checkmark$ Maxwell [1992] BCLC 475; see also the recent ruling by the Court of Appeal in $R v$ Secretary of State for Trade and Industry, ex $p$ McCormick, The Times, 10 February 1998) and the views of the Commission (which, as noted, tend to be less permissive) and the views of the court (whose collective view is almost impossible to fathom and predict). In the meantime, one can only hope that the court will soon have the opportunity to pronounce more definitively than it did in Saunders on this important topic. It is submitted that, like other areas of European law, subsidiarity should apply, thereby leaving member states to decide which public interest should prevail: the right to silence or the public interest in the detection and prosecution of serious crime. (c)

\section{Dr John Breslin}

Barrister, Lecturer in Law, University College, Dublin

\section{What makes a good lawyer an expert?}

\section{Legal information as it happens}

New Law Publishing

- Proactive Daily Digest Service

- Selects, edits and delivers on the same day as judgment

- Cross-referenced and indexed database of judgments

Fourth Floor, Quality House, Quality Court, Chancery Lane, London WC2A IHP Tel: 01714055434 Fax: 01714055693 E-Mail: info@newlawonline.com 